\title{
Editorial
}

\section{Peter Crittenden - A liber amicorum}

This first issue of The Lichenologist Volume 53 (2021) is dedicated to Peter Crittenden, in recognition of his long years of service to the journal, the British Lichen Society and lichenology worldwide. With Volume 52 (2020), Peter handed the responsibilities of Senior Editor to his successors, Leena Myllys and Christopher Ellis. On completing this transition there was universal assent among the associate editors who had served with Peter, and close friends, that the depth of gratitude felt for Peter's work should be expressed in a Special Issue, bringing together a series of papers on a wide breadth of subjects.

Peter's association with the journal began in 1997 (Volume 29) as part of the team assisting the then Senior Editor, Dennis Brown. He assumed joint senior editorship with Dennis in 2000 (Volume 32), and sole senior editorship with part 3 of that volume. Throughout this time Peter held a senior, full-time academic position at the University of Nottingham, as a researcher, teacher and supervisor of numerous postgraduate students and postdoctoral fellows, while managing large grants that took him as far afield as Antarctica and the Arctic, Namibia and Tasmania. During fieldwork in often remote places, he established contacts with local lichenologists and created a network that helped him build an international research team. A generation of lichen ecologists and ecophysiologists earned their stripes in Peter's lab, and it is no accident that one of these has inherited his duties as Senior Editor of The Lichenologist.

Lichen-nutrient relationships have been Peter's major research theme and, together with his co-workers, he published many influential papers on this topic. These included a seminal paper in The Lichenologist that established the role of the necromass in matforming lichens, ${ }^{1}$ guiding an understanding of lichens as 'ecosystem engineers' where they dominate the ground layer in boreal forests. Lateral thinking in pursuit of new ideas was a hallmark of Peter's work and is well characterized by his use of lichens to explore nutrient transfer from the marine to terrestrial realms. ${ }^{2}$ Peter's interests were broad, and significant research was also directed to population biology, lichen breeding systems and global environmental change, with papers appearing in specialist journals (e.g. Mycologist, The Lichenologist), through thematic ecological literature (e.g. Ecology Letters, New Phytologist) to the highest impact outlets (e.g. Nature). The international standing of Peter's work was reflected by his receipt of the Acharius Medal in 2014.

Although a highly productive scientist, Peter's dedication to the journal has been extraordinary. Having inherited a product of an already high standard and reputation, his vision and commitment took it to ever greater heights. He increased its volume and academic standing and modernized its look and feel with a new front cover, colour figures, on-line submission and other tweaks. Building on the efforts of his predecessor, he also strengthened the international composition of a strong team of associate editors to help with refereeing and managing papers through to acceptance. He also instigated the role of Managing Editor, initially held by his colleague the late Tony Braithwaite, and subsequently by his wife Margaret. Without this essential support, holding down a full-time academic job and being Senior Editor would not have been possible.

Readers of the journal and contributors of manuscripts will know The Lichenologist for its exceptional quality, where multiple sets of eyes ensure polished English prose, logical and consistent layout and style, error-free copy and high-quality reproduction. Closer friends of Peter will have witnessed the details of this process, with each paper personally overseen by him. There would have been few corners of Peter's universe where one would not see a manuscript proof and green pen close at hand: at the breakfast table or by his bedside, and while travelling by plane, train or car. Copy was checked at the cinema, or in the pub, and even when on holidays in distant places, the journal and the progress of papers was always foremost in Peter's mind.

After a term of some 20 years as Senior Editor, Peter stands as the longest serving bearer of that office, following in the footsteps of Dennis Brown, David Hawksworth and Peter James. In that time, he has overseen the publication of 118 issues of the journal, amounting to 1125 papers and almost 13000 pages. These include commemorative issues for senior figures in lichenology, such as Ernie Brodo, Brian Coppins, Ana Crespo, Hildur Krog and Ingvar Kärnefelt, as well as thematic issues dealing with symposia through to particular taxonomic challenges. In a recent Editorial marking the 50th volume of The Lichenologist, Peter reflected on how the journal had contributed to the careers of the authors of the first volume, and their legacies with respect to growth of academic knowledge, students trained and publication output. The same sentiments can certainly be expressed in glancing back over two decades of the 'Crittenden years'. On behalf of lichenologists everywhere who have benefited through having their papers published, or who have kept in touch with developments in their field through the papers of others, we say a sincere thank you to Peter and wish him happy and productive years ahead.

\section{References}

1. Crittenden PD (1991) Ecological significance of necromass production in mat-forming lichens. Lichenologist 23, 323-331.

2. Crittenden PD, Scrimgeour CM, Minnullina G, Sutton MA, Tang YS and Theobald MR (2015) Lichen response to ammonia deposition defines the footprint of a penguin rookery. Biogeochemistry 122, 295-311. 